\title{
Assessment of pre- and post-operative nutritional status in patients undergoing orthognathic surgery
}

\author{
Avaliação do estado nutricional pré e pós-operatório em pacientes submetidos \\ à cirurgia ortognática
}

Geórgia Alvares de Castro ${ }^{1}$ (D), Vanessa Alvares de Castro² (D), Rose Patin ${ }^{3}$ (D), Carlos Alberto Nogueira-de-Almeida 4 (D)

\begin{abstract}
Introduction: The maxillofacial procedures for skeletal deformities are characterized by structural-morphological changes derived from unfavorable genetics with diagnosis performed during craniofacial growth. Orthognathic surgery requires a total restriction on chewing for 60 days, leading to loss of body weight in overweight and obese individuals, as well as in well-nourished patients. Objective: Evaluating the pre- and post-operative nutritional status of patients undergoing orthognathic surgery. Material and methods: This is an interventional study. The study group received supplementation with whey protein, L-arginine, L-glutamine, and fatty acid Omega-3, and both groups were assessed in terms of anthropometric and biochemical measurements. The evaluation of soft tissue healing was conducted after surgery. Results: It is possible to infer that the percentage of skeletal muscle mass tends to increase in the intervention group, however, the weight loss was greater $(-4.88 \%)$. Uric acid increased post-operative in the control group $(+37.64 \%)$. Conclusion: Oral nutritional supplementation used in the study seems promising for reducing the loss of skeletal muscle mass, but further studies involving a larger number of patients are needed to confirm the results.
\end{abstract}

Keywords: Orthognathic Surgery; Nutritional Assessment; Arginine; Glutamine; Whey Protein.

\section{RESUMO}

Introdução: Os procedimentos maxilofaciais para deformidades esqueléticas são caracterizados por intervenções morfológicas estruturais, necessários por conta de genética desfavorável com diagnóstico feito durante o crescimento craniofacial. A cirurgia ortognática requer uma restrição total na mastigação por 60 dias, levando à perda de peso corporal em indivíduos com sobrepeso e obesos, bem como em pacientes bem nutridos. Objetivo: Avaliar o estado nutricional pré e pós-operatório dos pacientes submetidos à cirurgia ortognática. Material e métodos: Trata-se de um estudo de intervenção. O grupo de estudo recebeu suplementação com proteína de soro de leite, L-arginina, L-glutamina e ácido graxo ômega-3 e ambos os grupos foram avaliados em termos de medidas antropométricas e bioquímicas. A avaliação da cicatrização de tecidos moles foi realizada após a cirurgia. Resultados: É possível inferir que o percentual de massa muscular esquelética tendeu a aumentar no grupo de intervenção, porém a perda de peso foi maior $(-4,88 \%)$. O ácido úrico aumentou no pós-operatório no grupo controle ( $+37,64 \%)$. Conclusão: A suplementação nutricional oral utilizada no estudo parece promissora para reduzir a perda de massa muscular esquelética, mas estudos adicionais envolvendo um número maior de pacientes são necessários para confirmar os resultados.

Palavras-chave: Cirurgia Ortognática; Avaliação Nutricional; Arginina; Glutamina; Proteína do Soro.

1. Doctor, Viva Nutrição Institute, São Paulo (SP), Brazil.

2. Doctor, Vanessa Castro Clinics, Salvador (BA), Brazil.

3. Professor, Paulista University (UNIP), São Paulo (SP), Brazil.

4. Pos-Doctoring student, FMRP-USP, Professor, Federal University of São Carlos (UFSCAR), São Carlos (SP), Brazil.

$\square$ Carlos Alberto Nogueira-de-Almeida. Rua Eugênio Ferrante, 170, Jd. Nova Aliança Sul. CEP 14027-150. Ribeirão Preto (SP) Brasil. dr.nogueira@me.com | Recebido em: 30/03/2020 | Aprovado em: 11/08/2020 


\section{INTRODUCTION}

Maxillofacial skeletal deformities affect a significant proportion of the world's population, being characterized as structural and morphological changes, deriving from unfavorable genetics and diagnosed during craniofacial growth. These deformities lead to esthetic and functional impairment, such as difficulty in chewing, swallowing, diction, and breathing. Orthognathic surgery is a procedure that aims to establish the anatomic and functional equilibrium of facial bones, through maxillary and mandibular osteotomies, correcting these dentofacial disharmonies and restoring the individual's maxillary stability, normal breathing, and chewing patterns as well as improving self-esteem ${ }^{1}$.

A study conducted by Figueiredo et al. ${ }^{2}$ on the importance of nutritional monitoring in patients subjected to orthognathic surgery, through a comparative analysis of anthropometric and laboratory results measured during pre- and postoperative periods, concluded that nutritional therapy in the post-operative period with a hypercaloric diet and supplements helps to maintain indices of nutritional status at levels similar to those obtained in pre-op. The results showed that there was very little loss of body weight, which was regained over the course of the study, and maintenance of nutritional laboratory indicators. Worrall ${ }^{3}$ conducted a non-randomized, prospective pilot study for four months to evaluate the body composition of patients subjected to maxillofacial surgery via four skin folds, which were determined by clinical evaluation. The conclusion suggests that the investigation should continue to identify changes in body weight and composition after intermaxillary fixation surgery, due to loss of water, fat, and protein.

Surgical trauma can lead to intense inflammation and impairment of the ability to fight infection. In this regard, the nutrients used in the perioperative period may be useful in minimizing this trauma. Several studies have demonstrated the anti-inflammatory action of glutamine, benefitting the function of macrophages and neutrophilic phagocytosis and also preserving intestinal function and permeability 4,5 . Another ingredient with antiinflammatory action is fish oil, composed of fatty acids with very long chains in the omega- 3 series ${ }^{6}$. According to Waitzberg ${ }^{7}$, arginine, omega-3 fatty acid, and glutamine are immunonutrients used in enteral formulae that interfere with immunological competence. Arginine offers protection in ischemia/ reperfusion, increases mitogenic response, secretes growth hormone IGF-1 (a growth factor similar to insulin), glucagon, pancreatic polypeptide, vasopressin, and adrenal catecholamines, prevents thymic atrophy, improves the function of macrophages after injury, improves resistance to bacterial infection, inhibits the translocation of NFk-B, the secretion of IL-2 (interleukin) and IFNgamma (interferon) via Th-1, diminishes the release of IL-6, blocks the adhesion molecules, and inhibits lipid peroxidation ${ }^{8,9}$, leading to an improvement in the immune response ${ }^{10}$.

Omega-3 fatty acid modulates the synthesis of eicosanoids, acts as a potent anti-inflammatory, regulating membrane fluidity, interferes with the coagulation pathway, and diminishes the production of IL-1, IL-6, IL-1Beta, and TNF (tumor necrosis factor $)^{7,10}$. Glutamine acts by helping nitrogen transport between organs, reduces protein loss during stress, benefits function of macrophages and neutrophilic phagocytosis, increases the function of lymphocytes, and preserves intestinal function and permeability ${ }^{7}$. Arginine has metabolic, biological, and immunological functions and, in conditions of trauma, the organism requires larger quantities of this nutrient ${ }^{11}$. In animal models, the healing process improves when supplementation with arginine is used, reducing the occurrence of fistulas and occasionally helping with tissue reepithelialization, and can also help the soft tissue to heal ${ }^{12}$, but this has not been fully demonstrated in humans ${ }^{13}$.

This study aims to evaluate the pre- and post-operative nutritional status of patients subjected to orthognathic surgery when prescribed with the following oral supplements: whey protein, L-arginine, L-glutamine, and omega-3 as part of a hyperproteic diet.

\section{MATERIAL AND METHODS}

This is a prospective, experimental casecontrol study, with randomized controlled intervention, involving human beings. All patients voluntarily signed the Free and Informed Consent form, being aware of the purpose of the study. 
The study was conducted on 11 patients, seven of which were placed in the test group (with nutritional intervention) and four in the control group (without nutritional intervention), and both groups consisted of patients with dentoskeletal deformities, who were subjected to elective orthognathic surgery under general anesthetic, monitored by a senior team of Salvador, Bahia, Brazil. The project was approved by the Ethics Committee at the Universidade Paulista, Plataforma Brasil, no. 1.825.470.

Both groups, study and control, followed a hyperproteic and hypercaloric diet. The surgical techniques employed to correct the dentoskeletal deformities varied according to the planning of each case. The procedures were conducted by a single senior surgeon. All the patients began their oral supplements seven days before surgery and were hospitalized for a period of 48 hours, with the oral diet being started immediately after the surgery.

The evaluation intervals employed in this retrospective, randomized controlled study were as follows:

T1: one week prior to the orthognathic surgery (pre-op) (post-op)

T2: 10-15 days after the orthognathic surgery

The study group received daily oral nutritional supplements with $0.2 \mathrm{~g} / \mathrm{Kg}$ L-glutamine, $0.04 \mathrm{~g} / \mathrm{Kg}$ L-arginine, omega-3: $1000 \mathrm{mg}$, and $1.5 \mathrm{~g} / \mathrm{Kg}$ of whey protein (Nutri Protein HWP ${ }^{\circledR} ; 386 \mathrm{kcal} / 100 \mathrm{~g}$; in which $83 \%$ of the whey protein was hydrolyzed). The study group began the oral nutritional supplementation seven days before the surgery.

The I-arginine supplement was conducted using Targifor $^{\circledR}$ (850.3 mg of I-arginine and 1500 $\mathrm{mg}$ of arginine aspartate).

The inclusion criteria for the definition of the patients applied to both sexes; aged over 18 , different ethnic groups, and with referral to orthognathic surgery after a clinical imaging examination. The exclusion criteria applied to those individuals who did not undergo nutritional, clinical, and laboratory evaluation in the pre- and post-operative periods, according to the guidelines of this study, and/or presented with active gastrointestinal disturbances or morbidities, and also those who smoked.

Considering all the patients who were undergoing orthodontic treatment and were eligible for orthognathic surgery, there were fifty patients. The surgery took place between June and October 2016, and ten patients were excluded from the study, mostly due to the length it took for the health insurers to furnish approval. Of the remaining forty patients, only thirty satisfied the inclusion criteria as six were excluded due to gastrointestinal disturbances, while another four had associated morbidities, such as diabetes (two), hypercholesterolemia (one), and hypertriglyceridemia (one).

The remaining thirty patients began the study, fifteen in each group (test and control), were selected at random. However, ten patients over the course of the study did not undergo biochemical examinations either before or after the surgical procedure, and nine patients did not do the bioelectrical impedance examination, which excluded them from the results of the statistical evaluation between the intervals (pre- and post$o p)$, as well as from the comparison between the control group and test group. In the final evaluation of the study, seven patients from the test group were included and four from the control group.

The pre-op examinations conducted are those usually performed in the clinic, i.e., complete blood count, hemoglobin, hematocrit, erythrocytes, lymphocytes, neutrophils, and platelets, blood clotting, fasting blood sugar, AST, ALT, sodium, potassium, urine summary, ECG, thoracic $x$-ray, T3, $\mathrm{T} 4$, uric acid, urea, and creatinine. Also, a nutritional evaluation was carried out as well as biological markers of nutritional status (total proteins, albumin, globulin, and transferrin), immediately following pre-op.

At $T 2$, the predefined post-op interval, the following laboratory analyses were conducted: complete blood count, hematocrit, erythrocytes, lymphocytes, neutrophils and platelets, fasting blood sugar, T3, T4, AST, ALT, sodium, potassium, urine summary, uric acid, urea and creatinine, and the following biological markers of the nutritional status: total proteins, albumin, globulin, and transferrin.

The evaluation of nutritional status and body composition was conducted by anthropometric ${ }^{14}$ measurements (weight and height for the calculation of body mass index, as per the formula BMI = Weight (Kg) / Height ${ }^{2}\left(\mathrm{~m}^{2}\right)$, and percentages of fat and non-fatty mass via bioelectrical impedance (OMRON HBF-514C), in pre-op and post-op, for the control and intervention groups. 
The surgical techniques employed to correct the deformity were: osteotomy of the upper and lower jaws and stabilization of the osteotomized segments based on rigid internal fixation (RIF) with titanium plates and screws. The patients were not fitted with arch bars, rather they used intermaxillary elastics for 30 days, as per the technique described by Esteves et al. ${ }^{15}$ and De Souza et al. ${ }^{16}$.

The patients involved in the study (test group) were subjected to daily nutritional supplementation with $0.2 \mathrm{~g} / \mathrm{Kg}$ L-glutamine, $0.04 \mathrm{~g} / \mathrm{Kg}$ L-arginine, omega-3: $1000 \mathrm{mg}$ and $1.5 \mathrm{~g} / \mathrm{Kg}$ of whey protein (Nutri Protein HWP ; $386 \mathrm{kcal} / 100 \mathrm{~g}$; in which $83 \%$ of the whey protein was hydrolized) in pre-op (one week prior to the surgical procedure) and in post-op, including during the period of hospitalization, in addition to the oral diet, conducted in the hospital environment, and without enteral or parenteral nutrition.

For the control group, a standard hyperproteic and hypercaloric supplementation with Nutridrink MAX (Danone) was applied twice a day amounting to $600 \mathrm{kcal}$ and $30 \mathrm{~g}$ of protein.

In the immediate post-op during the period of hospitalization, the patients in the control and test groups were subjected to an oral diet of cold liquids, excluding milk and dairy products, every two hours, as prescribed by the surgeon. After discharge, the patients were instructed to observe a strict hypercaloric and hyperproteic diet, in both groups. The initially recommended diet had a liquid consistency which progressed to semiliquid to pasty diet, but with the same caloric value, depending on the patient, on average $2,600 \mathrm{Kcal}$ a day, adjusted for individual needs according to normal age-related weight and height, such as physical activity, thermogenic factors and injuries $(F=1,2)$, remaining for the duration of the study.

The diet recommended by the nutritional team in charge was based on the use of high energy density and hypercaloric foods such as olive oil, preparations such as fruit cocktails, milkshakes, ice cream, soups, and creams specified on the menu. The diet was divided into eight daily meals at twohourly intervals (daily average of 2,000 kcal), with the addition twice a day of Nutridrink Max $(200 \mathrm{~mL}$, $300 \mathrm{kcal}$, and $15 \mathrm{~g}$ of protein) nutritional supplement, or another equivalent oral nutritional supplement, as it consists of an adequate nutritional composition (high-energy value, rich in protein, carbohydrates, minerals, and fiber) which is inexpensive and easy to find, amounting to $2,600 \mathrm{kcal}$ a day, though for both groups a daily minimum of $2,000 \mathrm{kcal}$ was guaranteed.

The biochemical parameters and nutritional markers were collected and noted from the surgical/clinical file after delivery of the laboratory results. The paired t-test was used to check for the presence of significant differences in the laboratory examinations and parameters measured through bioelectrical impedance for the evaluation of delta in the same group between time intervals T1 and T2 (pre- and post-op), and for the comparison between the two groups, the Mann-Whitney test was used. Associations with $\mathbf{p}$-value $<\mathbf{0 . 0 5}$ were considered statistically significant.

\section{RESULTS}

The results of the anthropometric and biochemical evaluations of eleven patients were collected from the patient files and divided at random into two groups, control and test, following the described methodology. The characterization of the control and test groups can be observed in Tables 1 and 2, with the respective means and standard deviations for each variable assessed. It can be seen that age, weight, height, and body mass index (BMI) in the test group, between T1 (pre-op) and T2 (post-op) showed a significant statistical reduction for the weight $(p=0.019)$ and also BMI $(p=0.016)$, while for the control group, there was also a reduction, but with no statistically significant difference.

The percentages for total and visceral body fat, measured through the bioelectrical impedance examination, showed a reduction in both groups between time intervals $\mathrm{T} 1$ and $\mathrm{T} 2$. In the test group, there was no statistical difference in the percentage of total body fat $(p=0.095)$; however, there was for the percentage of visceral fat $(p=0.015)$. The skeletal muscle mass percentage rose for the test group between pre- and postop, but with no statistically significant difference $(p=0.142)$. On the other hand, in the control group, there was a reduction in the percentage of skeletal muscle mass, with no significant difference in the statistical evaluation. 
Table 1

Characterization of the test and control group in terms of the anthropometric results

\begin{tabular}{|c|c|c|c|c|c|}
\hline & \multicolumn{2}{|c|}{ Test Group $(\mathbf{N}=7)$} & \multicolumn{2}{|c|}{ Control Group $(N=4)$} & \\
\hline & Start (T1) & After 15 days (T2) & Start (T1) & After 15 days (T2) & \\
\hline & Mean (+ $(\underline{S D})$ & Mean (+SD) & Mean (土SD) & Mean (+SD) & \\
\hline Age (years) & $36.43 \pm 12.05$ & & $25.75 \pm 8.05$ & & NS \\
\hline Weight (Kg) & $72.37 \pm 15.17^{1}$ & $68.83 \pm 14.51$ & $75.32 \pm 18.60$ & $74.45 \pm 17.65$ & \\
\hline Height (m) & $1.73 \pm 0.08$ & & $1.75 \pm 0.12$ & & \\
\hline BMI $\left(\mathrm{Kg} / \mathrm{m}^{2}\right)$ & $23.99 \pm 2.91^{2}$ & $22.96 \pm 2.77$ & $25.11 \pm 3.69$ & $24.55 \pm 2.93$ & \\
\hline \multicolumn{6}{|c|}{ Bioelectrical impedance } \\
\hline Total fat (\%) & $24.13 \pm 5.89^{3}$ & $22.37 \pm 6.62$ & $27.22 \pm 11.64$ & $26.78 \pm 8.51$ & \\
\hline Visceral fat (\%) & $6.86 \pm 6.86^{4}$ & $5.71 \pm 2.63$ & $9.00 \pm 4.00$ & $7.25 \pm 2.63$ & \\
\hline Muscle (\%) & $34.03 \pm 5.23^{5}$ & $35.23 \pm 4.59$ & $43.72 \pm 28.83$ & $42.82 \pm 26.88$ & \\
\hline
\end{tabular}

Paired t-test ${ }^{1} p=0.019 ;{ }^{2} p=0.016 ;{ }^{3} p=0.095 ;{ }^{4} p=0.015 ;{ }^{5} p=0.142$

Table 2

Effect of nutritional intervention for the control and test groups in terms of anthropometric results

\begin{tabular}{|c|c|c|c|}
\hline & \multicolumn{3}{|c|}{$\begin{array}{c}\text { Test Group }(\mathrm{N}=7) \\
\text { Control Group }(\mathrm{N}=4)\end{array}$} \\
\hline & $\begin{array}{l}\text { Test Group } \\
\text { Delta \% }\end{array}$ & $\begin{array}{c}\text { Control Group } \\
\text { Delta \% }\end{array}$ & \multirow[t]{2}{*}{$\mathbf{P *}$} \\
\hline & Mean (土SD) & Mean (土SD) & \\
\hline Weight (Kg) & $-4.88(3.62)$ & $-1.02(1.42)$ & 0.089 \\
\hline BMI $\left(\mathrm{Kg} / \mathrm{m}^{2}\right)$ & $-4.25(2.94)$ & $-1.97(2.83)$ & 0.257 \\
\hline \multicolumn{4}{|l|}{ Bioelectrical impedance } \\
\hline Total Fat (\%) & $-8.02(10.65)$ & 3.65 (18.09) & 0.186 \\
\hline Visceral Fat (\%) & $-17.62(13.70)$ & $-19.30(18.02)$ & 0.562 \\
\hline Muscle (\%) & $4.09(6.57)$ & $-0.95(4.57)$ & 0.186 \\
\hline
\end{tabular}

*Mann Whitney $p>0.05$ NS

Comparing intervals $\mathrm{T} 1$ (pre-op) and $\mathrm{T} 2$ (post-op) for the same group, i.e. the test group or control group, it can be seen that the weight in the test group did not fall more than in the control group, as the difference was not statistically significant $(p=0.089)$. The same was true for BMI; in other words, it did not fall more than in the test group, as there was no statistically significant difference $(p=0.257)$. With the comparison of the percentage of body fat, a reduction of $8.02 \%$ was observed in the test group and an increase of $3.65 \%$ in the control group, though the difference between the two groups was not statistically significant $(p=0.186)$. As for the percentage of skeletal muscle mass, this rose by $4.09 \%$ in the test group and fell $0.95 \%$ in the control group, with no statistical significance between the groups $(p=0.186)$. However, the percentage of visceral fat did not fall in either group when comparing pre-op (T1) and post-op (T2), as there was no statistically significant difference between the test and control groups $(p=0.568)$.

Tables 3, 4, 5, and 6 show the most relevant results. Blood sugar fell between T1 and T2 (preand post-op) for the two groups, with statistical significance in the test group $(p=0.0087)$ and the control group $(p=0.0033)$. The reduction in blood sugar did not attain levels of hypoglycemia (fasting blood sugar $<50 \mathrm{mg} / \mathrm{dL}$ for adults, according to authors ${ }^{17,18}$. However, there was a reduction that may be due to the low intake of foods in post-op, with the introduction of only a liquid diet, even though this was a dietary recommendation with the use of high energy density and hypercaloric foods. 
Table 3

Characterization of the test and control groups in terms of the results of the biochemical examinations

\begin{tabular}{|c|c|c|c|c|}
\hline & \multicolumn{2}{|c|}{ Test Group $(\mathrm{N}=7)$} & \multicolumn{2}{|c|}{ Control Group $(\mathrm{N}=4)$} \\
\hline & $\begin{array}{c}\text { Start } \\
(\mathrm{T} 1) \\
\text { Mean (土SD) }\end{array}$ & $\begin{array}{c}\text { After } 15 \text { days } \\
\text { (T2) } \\
\text { Mean (土SD) }\end{array}$ & $\begin{array}{c}\text { Start } \\
(\mathrm{T} 1) \\
\text { Mean (土SD) }\end{array}$ & $\begin{array}{c}\text { After } 15 \text { days } \\
\text { (T2) } \\
\text { Mean ( } \pm S D)\end{array}$ \\
\hline Blood Sugar & $91.14 \pm 5.24^{1}$ & $84.57 \pm 6.996$ & $90.5 \pm 12.90^{2}$ & $83.5 \pm 11.36$ \\
\hline Urea & $32 \pm 12.57^{5}$ & $26.43 \pm 12.04$ & $31.25 \pm 9.71^{6}$ & $28.5 \pm 7.14$ \\
\hline Creatinine & $0.88 \pm 0.18^{3}$ & $0.83 \pm 0.21$ & $0.95 \pm 0.20^{4}$ & $0.89 \pm 0.20$ \\
\hline Uric acid & $3.82 \pm 1.17^{7}$ & $3.46 \pm 1.05$ & $3.75 \pm 1.55^{8}$ & $5.02 \pm 1.88$ \\
\hline Total protein & $7.18 \pm 0.38^{9}$ & $6.81 \pm 0.43$ & $7.10 \pm 0.46^{10}$ & $6.92 \pm 0.26$ \\
\hline Albumin & $4.38 \pm 0.26^{11}$ & $3.7 \pm 1.02$ & $4.32 \pm 0.36^{12}$ & $4.1 \pm 0.18$ \\
\hline Transferrin & $229.86 \pm 73.73^{13}$ & $214.43 \pm 69.03$ & $247.25 \pm 36.44^{14}$ & $249.25 \pm 40.02$ \\
\hline Globulin & $2.80 \pm 0.38^{15}$ & $2.76 \pm 0.30$ & $2.78 \pm 0.81^{16}$ & $2.82 \pm 0.4031$ \\
\hline \multicolumn{5}{|c|}{$\begin{array}{l}\text { Paired t-test }{ }^{1} p=0.0087 ;{ }^{2} p=0.0033 ;{ }^{3} p=0.3632 ;{ }^{4} p=0.4912 ;{ }^{5} p=0.0205 ;{ }^{6} p=0 \\
p=0.1141 ;{ }^{12} p=0.2946 ;{ }^{13} p=0.0147 ;{ }^{14} p=0.7739 ;{ }^{15} p=0.7716 ;{ }^{16} p=0.8825\end{array}$} \\
\hline \multicolumn{5}{|l|}{ Table 4} \\
\hline \multicolumn{5}{|c|}{ Effect of nutritional intervention in the control and test groups in terms of the biochemical results } \\
\hline & \multicolumn{4}{|c|}{$\begin{array}{c}\text { Test Group }(\mathrm{N}=7) \\
\text { Control Group }(\mathrm{N}=4)\end{array}$} \\
\hline & \multicolumn{2}{|c|}{$\begin{array}{l}\text { Test Group } \\
\text { Delta \% }\end{array}$} & $\begin{array}{c}\text { Control Group } \\
\text { Delta \% }\end{array}$ & $\mathbf{P *}$ \\
\hline & \multicolumn{2}{|c|}{ Mean (土SD) } & Mean ( $(\underline{\mathbf{S D}})$ & \\
\hline Blood Sugar & \multicolumn{2}{|c|}{$-7.24 \pm 5.07$} & $-7.67 \pm 0.90$ & 0.344 \\
\hline Urea & \multicolumn{2}{|c|}{$-16.73 \pm \_15.52$} & $-6.04 \pm 22.40$ & 0.571 \\
\hline Creatinine & \multicolumn{2}{|c|}{$-4.65 \pm 11.50$} & $-6.21 \pm 18.38$ & 0.924 \\
\hline Uric acid & \multicolumn{2}{|c|}{$-7.71 \pm 16.91$} & $37.64 \pm 23.28$ & 0.008 \\
\hline Total protein & \multicolumn{2}{|c|}{$-5.16 \pm 3.26$} & $-2.35 \pm 3.62$ & 0.345 \\
\hline Albumin & \multicolumn{2}{|c|}{$-15.60 \pm 22.22$} & $-4.74 \pm 7.70$ & 0.500 \\
\hline Transferrin & -6.2 & & $0.75 \pm 5.18$ & 0.089 \\
\hline Globulin & -0.47 & 75 & $7.14 \pm 27.82$ & 0.705 \\
\hline
\end{tabular}

*Mann Whitney $p>0.05$ NS

\section{Table 5}

Characterization of the test and control groups in terms of the results of the biochemical examinations (TG, cholesterol, and fractions)

\begin{tabular}{|c|c|c|c|c|}
\hline & \multicolumn{2}{|c|}{ Test Group $(\mathbf{N}=7)$} & \multicolumn{2}{|c|}{ Control Group $(N=4)$} \\
\hline & $\begin{array}{c}\text { Start } \\
\text { (T1) } \\
\text { Mean (+SD) }\end{array}$ & $\begin{array}{c}\text { After } 15 \text { days } \\
\text { (T2) } \\
\text { Mean ( }(\underline{S D})\end{array}$ & $\begin{array}{c}\text { Start } \\
(\mathrm{T} 1) \\
\text { Mean (프) }\end{array}$ & $\begin{array}{c}\text { After } 15 \text { days } \\
\text { (T2) } \\
\text { Mean (+SD) }\end{array}$ \\
\hline TG & $79.28 \pm 20.15^{1}$ & $97 \pm 22.32$ & $101.25 \pm 47.67^{2}$ & $154.25 \pm 71.89$ \\
\hline $\mathrm{TC}$ & $150.43 \pm 14.83^{3}$ & $164.14 \pm 16.77$ & $190.25 \pm 37.37^{4}$ & $207.75 \pm 30.61$ \\
\hline LDL & $87.48 \pm 14.08^{5}$ & $99.71 \pm 14.89$ & $130.25 \pm 35.51^{6}$ & $135.55 \pm 38.03$ \\
\hline HDL & $65 \pm 25.13^{7}$ & $44.71 \pm 9 . .32$ & $40.6 \pm 5.63^{8}$ & $41.27 \pm 10.88$ \\
\hline
\end{tabular}

Paired t-test, ${ }^{1} p=0.0084 ;{ }^{2} p=0.2600 ;{ }^{3} p=0.1466 ;{ }^{4} p=0.1641 ;{ }^{5} p=0.1715 ;{ }^{6} p=0.6297 ;{ }^{7} p=0.0998 ;{ }^{8} p=0.8554$ 
Table 6

Effect of nutritional intervention for the control and test groups in terms of the biochemical results (TG, cholesterol, and fractions)

\begin{tabular}{cccc}
\hline & \multicolumn{3}{c}{ Test Group (N=7) } \\
& Control Group (N=4) \\
\cline { 2 - 4 } & $\begin{array}{c}\text { Test Group } \\
\text { Deelta \% } \\
\text { Mean (+SD) }\end{array}$ & $\begin{array}{c}\text { Control Group } \\
\text { Delta \% } \\
\text { Mean (+SD) }\end{array}$ & p* \\
\hline TG (triglycerides) & $23.71 \pm 15.9524$ & $69.625 \pm 112.3313$ & 0.130 \\
TC (total cholesterol) & $-4.65 \pm 11.4968$ & $-6.2125 \pm 18.3853$ & 1.000 \\
LDL (cholesterol fraction) & $16.5685 \pm 25.2277$ & $5.2825 \pm 17.3822$ & 0.705 \\
HDL (cholesterol fraction) & $-24.3485 \pm 24.5016$ & $0.8599 \pm 17.0518$ & 0.130 \\
\hline
\end{tabular}

*Mann Whitney $p>0.05$ NS

Uremia also fell in post-op only in the test group, and with a statistically significant difference $(p=0.0205)$.

In the control group, uric acid fell, and with statistical significance $(p=0.0362)$ in post-op $(\mathrm{T} 2)$, possibly due to the disequilibrium between intake, endogenous synthesis, glomerular filtration, and tubular handling which possess complex reabsorption and excretion systems ${ }^{17,18}$. Total proteins showed a statistically significant reduction in the test group $(p=0.0047)$ between time intervals $\mathrm{T} 1$ and $\mathrm{T} 2$. For the control group, there was no reduction due to the absence of a statistically significant difference.

Uric acid fell in the test group, while in the control group it rose, with a statistically significant difference $(p=0.008)$.

A different effect occurred with creatinine, which exhibited no statistically significant difference between T1 and T2 for both groups evaluated $(p=0.924)$.

The biomarkers of lipid metabolism: triglycerides, cholesterol, LDL-cholesterol, and HDLcholesterol increased in both study groups, except that in the test group HDL-cholesterol fell, but with no statistically significant difference compared to the control group $(p=0.130)$. With the triglycerides, a statistically significant difference was observed $(p=0.0084)$ in the test group between T1 and T2. The head surgeon of the Oral Maxillofacial team in Salvador evaluated the healing of the soft tissue by clinical examination and no complications were observed. All the patients in both groups evolved as expected, with the stitches being removed ten days after surgery, the surgical wounds healed satisfactorily.

\section{DISCUSSION}

Concerning body weight in relation to nutritional status after surgery, similar results were found by Jaworska et al. ${ }^{19}$, who concluded that there is a distinct relationship between a worsening of the nutritional status after craniofacial surgery and nutrition during and after hospitalization, thus special care should be provided to patients in terms of nutrition during this short post-operative period. Giacobbo et al..$^{20}$ also identified that there was serious weight loss in all patients ( $>2 \%$ of body weight per week) after orthognathic surgery. Accordingly, these authors suggest that the interaction between a nutritionist and oral maxillofacial surgeon is essential to plan properly a dietary intervention in the period after orthognathic surgery to minimize potential weight loss.

Another important aspect to be considered is food intake which, according to Kendell et al. ${ }^{21}$, who studied twenty-four patients subjected to orthognathic surgery to establish the impact of hypercaloric liquid nutritional supplements in preventing the catabolic process, concluded that the intake of nutrients in the experimental group (inclusion of hyperproteic supplement) remained similar to the pre-operative pattern, while in the control group (which only consumed liquified food ad libitum) the intake decreased significantly, mainly one week after surgery. This result demonstrates 
that, besides the addition of hypercaloric supplement to the diet, this also contributed to a greater intake of nutrients in the post-operative period at the same levels, consistent with pre-op.

After orthognathic surgery, patients experienced multiple fractures that contribute to a catabolic process in which, according to Palmo et al.22, who studied the nutritional requirements of 19 patients with maxillofacial trauma, these individuals had a greater need of calorific intake, having a positive protein balance only when they consumed at least $46 \mathrm{cal}$ per $\mathrm{Kg}$ per day.

It can be seen that the standard deviation found in the control group is greater than for the test group, mainly for the percentages of total body fat and skeletal muscle mass. This high standard deviation may be due to patients not having followed the pre-preparation protocol for the performance of the bioelectrical impedance examination, as well as the low number of patients in this control group (4).

The results displayed in Table 1 lead us to believe that the characterization of the test and control groups did not present statistically significant differences between the time intervals evaluated (pre- and post-op). Only weight, BMI, and the percentage of visceral fat reduced with a statistically significant difference in the test group, even with a different nutritional intervention using I-glutamine, I-arginine, omega-3, and whey protein for the group studied. Another important aspect to consider is the value of " $n$ ", the number of patients, which in the test group numbered only seven and in the control group just four.

By exploring the study's exclusion criteria, another possible cause was the low take-up in performing the biochemical and anthropometric examinations, bioelectrical impedance being the main difficulty. The majority of excluded patients sustained that they did not carry out supplementation adequately according to the methodology defined, i.e., they did not use the food supplements, as in the majority of situations they preferred homemade food, with a better taste and this food was sufficient to satisfy their hunger, not to mention the cost aspect.

As for body weight and BMI, other authors, Kendell BD et al. ${ }^{21}$, found results that differed from the present study, which confirm the maintenance of body weight and somatic proteins in the study group receiving supplement with a hyperproteic diet, when compared to the control group with only liquid intake.

The number of patients was possibly a pivotal factor in not observing the statistical difference. However, it is possible that no difference occurred. The tendency, however, is positive, seeing that the test group seemingly tends to show an increase in skeletal muscle mass, which may be due to the lower catabolic process in post-op, when the patient is experiencing acute oxidative stress ${ }^{7}$. Or even that this difference does not exist as no statistically significant difference between the test and control groups was identified.

The hypothesis of an increase in skeletal muscle mass in the test group was due to the supplementation with immunomodulators: I-glutamine, I-arginine, omega-3 for the patient who, in post-op (T2) had already been using supplements for about 20 and 22 days. Glutamine increases cellular glutathione, benefiting the cell's antioxidant activity. Whey protein showed that it can increase the cellular glutathione, benefiting cell proliferation and immune response, also due to certain peptides with stimulatory action, such as IL-2 and IFN- $y^{23-25 .}$

In post-op, a hypercatabolic condition may occur when the quantity of glutamine produced is not sufficient and, accordingly, the organism compensates for the protein input through the musculature. For preventing patients from muscle loss, glutamine supplement should be taken, because it is believed to reduce protein loss during stress and helps to improve response after surgery ${ }^{23}$.

Glutamine has a close relationship with healing events, participates as a gluconeogenesis substrate, supplying energy to inflammatory cells, and stimulating an early immune response. It is essential for lymphocyte proliferation, and an important precursor of the synthesis of nucleotides in fibroblasts and macrophages. Moreover, some of its metabolic end products (hydroxyproline, gamma-aminobutyrate, and glutathione) make up the structure of the collagen molecule ${ }^{23}$.

In post-op, the organism compensates for the low protein intake through the musculature. For sparing the patient from muscle loss, the intake of glutamine must be supplemented. Glutamine 
reduces protein loss during stress and helps to improve response after surgery ${ }^{23}$. Among these, supplements with fatty acids of the omega- 3 family may be one strategy to reduce the formation of proinflammatory cytokines, benefiting the metabolic tolerance of the energy substrates and decreasing protein catabolism to improve the prognosis for the cure of patients with cancer. However, studies have shown some conflicting results for supplementation with omega-3 concerning immune response. On the other hand, in cancer patients, clinical trials have shown it alleviates the inflammatory response and improves nutritional status ${ }^{26}$. This could be a hypothesis to explain the increase in skeletal muscle mass in the test group.

Concerning weight loss combined with a loss of lean mass, this is a phenomenon observed not only in patients subjected to orthognathic surgery ${ }^{2}$ but also frequently in cancer patients. This condition renders the patient susceptible to a greater risk of infection, poorer response to the implemented treatments, and, as a consequence, is unfavorable to a prognosis of cure. Moreover, malnutrition is also linked to a poorer quality of life. Thus, some therapies have been proposed in an attempt to reverse catabolism, through alleviation of inflammatory response observed in a high percentage of patients with cancer and cachexia. Among these, supplements with fatty acids from the omega- 3 family may be one strategy for reducing the formation of pro-inflammatory cytokines, benefiting the metabolic tolerance of the energy substrates and lessening protein catabolism to improve the prognosis for the cure of patients with cancer. However, studies have shown some conflicting results of supplementation with omega-3 related to immune response. On the other hand, in cancer patients, clinical trials have shown it alleviates inflammatory response and improves nutritional status ${ }^{26}$.

The fact that urea is reduced between T1 and T2 may be due to the low intake in the postoperatory period, as urea is synthesized in the liver from ammonia as an end product of protein catabolism. It is filtered through renal glomeruli and around $40-50 \%$ are reabsorbed in the proximal convoluted tubule. It reflects the endogenous protein breakdown (catabolism) or low exogenous intake ${ }^{17,18}$. The reduction in uric acid in the control group may be understood as lower reabsorption than in the test group, even though the patients in the two groups may have consumed a similar amount of protein.

The post-operative catabolic process may explain the weight loss when the endogenous muscle proteins are used, necessitating a higher exogenous intake, mainly in the immediate post-op when the administered diet was liquidbased, excluding milk and dairy products, using hyperproteic supplementation in both groups. Even in the test group, which took supplementation with immunomodulators (I-glutamine, l-arginine, and omega-3) and whey protein was the source of the supplementation, the drop in total proteins, albumin, transferrin, and globulin occurred with no statistically significant difference $(p=0.345$ and $p=0.500$, respectively) compared with the control group, which did not demonstrate an increase in transferrin and globulin $(p=0.089$ and $p=0.705$, respectively). Another important aspect to be considered with the loss of body weight is the consumption of reserve body fat in cachexia or catabolic processes ${ }^{7}$.

The change in uric acid, increased in the control group, may be due to the fact that uric acid is the end product of the catabolism of purines (adenine and guanine), mainly formed in the liver through xanthine through the action of the enzyme xanthine oxidase. Authors ${ }^{27}$ initially identified a relationship between metabolism of purines and protein intake, reporting that the nucleic acids should be synthesized from the amino acids, and thus may stimulate nuclear metabolism and help to increase the anabolism of the purines. Accordingly, the serum uric acid levels are high as a result of high protein intake, through an increase in the endogenous production of urate or through a reduction in the renal excretion of monosodium urate ${ }^{28}$. Individually, the levels of uric acid depend on genetically determined metabolic factors such as enzyme activity, nutritional factors and also the efficiency of renal excretion. Recent clinical, epidemiological evidence has suggested that hyperuricemia may be a risk factor for cardiovascular disease and metabolic syndrome in the long term, occasional spikes in acute conditions are not expected. Moreover, the involvement of uric acid with oxidative stress and the combination of 
these factors in the development of diseases has been the subject of investigation ${ }^{29}$.

Some authors ${ }^{29}$ have stated that serum uric acid concentrations are positively related to blood pressure, regional and total adiposity, fasting blood sugar, insulin, triglycerides, as well as being inversely related to levels of HDL cholesterol in adolescents and adults $^{30}$. These facts allow us to infer that the levels of serum uric acid and triglycerides exhibit correlation within the metabolic syndrome that has some similarities to the inflamed condition of these patients in the short-term post-operative period (10 to 15 days, T2). When uric acid increases, it may be related to acute infection, metabolic acidosis, stress, hyperlipidemia, or hypertension ${ }^{31}$. When there is a reduction, on the other hand, this may be for many reasons, including some medications, or hypercatabolic process, which may have occurred on account of low food intake, mainly protein, which was lower in the test group. One of the biomarkers of the protein metabolism is uric acid, as in studies on cancer patients that also present with a condition of protein catabolism ${ }^{7}$.

In the test group, triglycerides increased in post-op, perhaps due to the process of oxidative stress, though it is a different result from that found in post-op of patients with metabolic syndrome when it was observed that triglyceride values fell by $49.2 \%$. HDL-cholesterol rose $27.2 \%^{32}$. Similar results were found by another author ${ }^{33}$ who evaluated patients after intermaxillary fixation surgery and observed an increase in triglycerides, possibly due to the change in eating habits to a diet with low fat and high carbohydrate content, thereby increasing the synthesis of fatty acids and very lowdensity lipoprotein (VLDL).

Another interesting aspect to evaluate in future studies is the relationship of nitric oxide with triglyceride content, since authors ${ }^{34}$ have understood that the nitric oxide (NO) synthesized from the amino acid L-arginine by the enzyme NO synthase (NOS) plays a fundamental role in the cell functions, such as vasodilatation, inhibition of platelet aggregation, antioxidant, and antiproliferative effect, and higher levels of triglycerides were observed in the plasma, positively associated with the genotype CC (homozygous polymorphism) of the eNOS gene in position -786T $>C$, in middleaged women. Accordingly, the hypothesis may be raised that supplementation with I-arginine could elevate the triglyceride content of patients at $\mathrm{T} 2$ (post-op), however, based on the results of this study, the absolute values of triglycerides found in the control group are higher, but the difference with the test group is not statistically significant.

Protein intake through eating and also from the use of hyperproteic supplements was, for both groups, possibly not sufficient to achieve balance during the catabolic process following orthognathic surgery, a procedure which leads to multiple fractures and the fitting of titanium pins for bone reconstruction. Other authors ${ }^{22}$ studied nutritional requirements of 19 patients with maxillofacial trauma, and observed that individuals with severe, multiple fractures had a greater need for caloric intake, having a positive protein balance when they consumed a minimum of $46 \mathrm{cal} / \mathrm{Kg}$ a day. On the other hand, individuals with fewer fractures need less caloric intake, from both a practical and physiological aspect, associated with diet and the relationship with nutritional conditions and metabolic responses.

Even though the healing process has a better response using supplementation with arginine, due to the reduction in the occurrence of fistulas and benefits the tissue reepithelialization, with the formation of fibroblasts and angiogenesis, as well as better immune response ${ }^{7,23}$, the results found in the two groups were similar, leading to the belief that healing is related more to the surgical procedure than to the supplements used. In fact, the real contribution of arginine and glutamine supplementation at lean mass needs to be better understood ${ }^{35}$.

For a proper comparison, diets in the study (control and test) were hyperproteic and hypercaloric, enriched with vitamins and essential minerals.

Whey protein can maintain lean mass (skeletal muscular) due to its favorable amino acid profile, with higher leucine, isoleucine, and valine (branched-chain amino acids) content, in addition to its contribution to maintaining levels of cellular glutathione, which benefits immune response ${ }^{25}$. As the loss in body mass was significant, there is an increase in lean (muscular) mass in the test group, it is believed that this was due to supplementation using this protein.

Supplementation with L-glutamine, L-arginine, and omega-3 has an immunomodulation function, as L-arginine acts as a precursor for the increase in the 
levels of nitric oxide, improving the function of the red blood cells and acting on the immune response. L-glutamine is an amino acid glutathione precursor, a cellular antioxidant, and also reduces protein loss during stress, the surgical procedure ${ }^{7,10}$. Thus, for the study group, a better outcome is expected in terms of the immune system, healing, and anthropometric indicators. The biochemical indicators should be kept stable and this may occur 40 to 45 days after orthognathic surgery, as observed by other authors ${ }^{19}$. Although arginine and glutamine have relevant immunomodulator and anti-inflammatory effects, their ability to help lean mass recovery has not been convincingly shown among humans $8,9,11-13,23,36,37$.

From the results of this study, it may be inferred that weight, BMI, and percentage of visceral fat fell in the test group, though only the body weight fell $(4.88 \%)$ with a statistical significance compared with the drop occurring in the control group. This drop in body weight and, consequently, the BMI may be related to the low food intake in the post-operative period (10 to 15 days after surgery), when the patient is in an acute inflammatory state. For future studies, the recommendation is to monitor food intake in a more controlled way to check the possible correlation with the reduction in body weight. Another important point is to perform a study that can evaluate anthropometric and biochemical measurements 40 to 45 days (T3) after orthognathic surgery.

Blood sugar decreased in both study groups, although urea only decreased in the test group, as did the total proteins, including transferrin. A statistical difference was exhibited by uric acid, which increased by $37.64 \%$ in the control group, which was statistically significant when compared with the test group.

It may be concluded that the increase in triglycerides in the test group was not statistically significant when compared to the increase in the control group.

It was observed that the healing of the soft tissue was in line with expectations for both groups. The post-operative evaluation (T2) occurred 10 to 15 days after orthognathic surgery, when the patients were in an acute inflammatory state, possibly having an impact on the results found. The proposal is to conduct an anthropometric and biochemical evaluation at a third point in time (T3), 40 to 45 days after surgery.
Further studies should be conducted, but hyperproteic supplementation with whey protein and the immunomodulators I-glutamine, I-arginine, and omega-3 has some effect on the skeletal muscle mass of patients subjected to orthognathic surgery.

\section{REFERENCES}

1. Araujo A. Cirurgia ortognática. Cirurgia ortognática, 1999.

2. Figueiredo LMG, Carvalho MC, Sarmento VA, Brandão GRR, Oliveira TFLd, Carneiro Junior B, et al. Avaliação do estado nutricional pré e pós-operatório em pacientes submetidos à cirurgia ortognática: estudo piloto. Revista de Cirurgia e Traumatologia Buco-maxilo-facial. 2013;13:89-93,

3. Worrall SF. Changes in weight and body composition after orthognathic surgery and jaw fractures: a comparison of miniplates and intermaxillary fixation. British Journal of Oral and Maxillofacial Surgery. 1994;32:289-292.10.1016/0266-4356(94)90048-5

4. Wasinski F, Gregnani MF, Ornellas FH, Bacurau AV, Câmara NO, Araujo RC, et al. Lymphocyte glucose and glutamine metabolism as targets of the anti-inflammatory and immunomodulatory effects of exercise. Mediators Inflamm. 2014;2014:326803.10.1155/2014/ 326803

5. Jain P, Khanna NK. Evaluation of anti-inflammatory and analgesic properties of L-glutamine. Agents Actions. 1981;11:243-249.10.1007/bf01967621

6. Laubertová L, Koňariková K, Gbelcová H, Ďuračková Z, Muchová J, Garaiova I, et al. Fish oil emulsion supplementation might improve quality of life of diabetic patients due to its antioxidant and anti-inflammatory properties. Nutr Res. 2017;46:49-58.10.1016/j. nutres.2017.07.012

7. Waitzberg DL. Dieta, nutrição e câncer. Dieta, nutrição e câncer, 2004.

8. Nazarian B, Fazeli Moghadam E, Asbaghi O, Zeinali Khosroshahi M, Choghakhori R, Abbasnezhad A. Effect of I-arginine supplementation on $\mathrm{C}$-reactive protein and other inflammatory biomarkers: A systematic review and meta-analysis of randomized controlled trials. Complement Ther Med. 2019;47:102226.10.1016/j. ctim.2019.102226

9. Mirhafez SR, Hariri M. L-arginine effect on inflammatory mediators: A systematic review of randomized controlled clinical trials. Int J Vitam Nutr Res. 2019;10.1024/0300-9831/ a0006191-9.10.1024/0300-9831/a000619

10. Waitzberg DL, Torrinhas RS. Fish Oil Lipid Emulsions and Immune Response: What Clinicians Need to Know. Nutrition in Clinical Practice. 2009;24:487-499.10.1177/0884533609339071 
11. Wittmann F, Prix N, Mayr S, Angele P, Wichmann MW, van den Engel $\mathrm{NK}$, et al. L-arginine improves wound healing after trauma-hemorrhage by increasing collagen synthesis. J Trauma. 2005;59:162-168.10.1097/01. ta.0000171529.06625.a8

12. Shi HP, Wang SM, Zhang GX, Zhang YJ, Barbul A. Supplemental L-arginineenhanceswound healing following trauma/hemorrhagic shock. Wound Repair Regen. 2007; 15:66-70.10.1111/j.1524-475X.2006.00186.x

13. Loehe F, Bruns CJ, Nitsch SM, Angele MK. The role of L-arginine following trauma and blood loss. Curr Opin Clin Nutr Metab Care. 2007;10:80-87.10.1097/ MCO.0b013e328011bb1b

14. de Almeida CAN, Ricco RG. Avaliação do estado nutricional com ênfase à antropometria. Pediatria (São Paulo). 1998;20:385-398,

15. Esteves LS, Castro V, Prado R, de Moraes e Silva CÁV, do Prado CJ, Trindade Neto AI. Assessment of Skeletal Stability After Counterclockwise Rotation of the Maxillomandibular Complex in Patients With LongFace Pattern Subjected to Orthognathic Surgery. Journal of Craniofacial Surgery. 2014;25:432-436.10.1097/ scs.0000000000000395

16. de Sousa Miranda W, Álvares de Castro Rocha V, Lara dos Santos Marques K, Trindade Neto AI, do Prado CJ, Zanetta-Barbosa D. Three-dimensional evaluation of superior airway space after orthognathic surgery with counterclockwise rotation and advancement of the maxillomandibular complex in Class II patients. Oral Surgery, Oral Medicine, Oral Pathology and Oral Radiology. 2015;120:453-458.10.1016/j. 0ooo.2015.06.037

17. Mahan LK, Escott-Stump S. Krause, alimentos, nutrição \& dietoterapia: editora roca; 2005.

18. Prado FCd, Ramos JdA, Valle JRd. Atualização terapêutica. Atualização terapêutica. 24 ed: Artes Médicas; 2012.

19. Jaworska E, Lewandowski Z, Samolczyk-Wanyura D, Ławiński M, Pertkiewicz M. Method of Nutrition of Patients After Major Oral and Craniofacial Surgery and its Effects on BMI Changes During a Half-Year Period of Observation. Polish Journal of Surgery. 2014;86.10.2478/pjs-2014-0054

20. Giacobbo J, Mendel MIL, Borges WD, El-Kik RM, Oliveira RB, Silva DN. Acompanhamento de parâmetros nutricionais antropométricos de pacientes adultos submetidos a cirurgia ortognática. Rev Odonto Cienc. 2009;24:92-96,

21. Kendell BD, Fonseca RJ, Lee M. Post-operative nutritional supplementation for the orthognathic surgery patient. Journal of Oral and Maxillofacial Surgery. 1982;40:205-213.10.1016/0278-2391(82)90312-3

22. Palmo A, Romagnoli R, Zoppè L, Avagnina $S$, De AF, Balzola $F$, et al. Evaluation of the nutritional state of patients with maxillo-facial pathology. Minerva stomatologica. 1981;30:265-270,

23. Okawa L. Influência da suplementação enteral pré-operatória com dieta enriquecida com arginina, ácidos graxos ômega-3, nucleotídeos e oligoelementos na cicatrização de anastomoses colônicas em ratos. 2009,

24. Pacheco MTB, Dias NFG, Baldini VLS, Tanikawa C, Sgarbieri VC. Propriedades funcionais de hidrolisados obtidos a partir de concentrados protéicos de soro de leite. Ciência e Tecnologia de Alimentos. 2005;25.10.1590/ s0101-20612005000200026

25. Saint-Sauveur D, Gauthier SF, Boutin Y, Montoni A. Immunomodulating properties of a whey protein isolate, its enzymatic digest and peptide fractions. International Dairy Journal. 2008;18:260-270.10.1016/ j.idairyj.2007.07.008

26. Garófolo A, Petrilli AS. Balanço entre ácidos graxos ômega-3 e 6 na resposta inflamatória em pacientes com câncer e caquexia. Revista de Nutrição. 2006;19:611-621.10.1590/ s1415-52732006000500009

27. Taylor A, Rose W. The influence of protein intake upon the formation of uric acid. Journal of Biological Chemistry. 1914;18:519-520,

28. Coutinho T, Turner S, Peyser P, Bielak L, Sheedyii $P$, Kullo I. Associations of Serum Uric Acid With Markers of Inflammation, Metabolic Syndrome, and Subclinical Coronary Atherosclerosis. American Journal of Hypertension. 2007;20:83-89.10.1016/j. amjhyper.2006.06.015

29. Moresco N. Ácido úrico como fator de risco para doenças cardiovasculares e síndrome metabólica. Rev Bras Farm. 2011;92:3-8,

30. Cury-Boaventura MF, Torrinhas RSMdM, Godoy ABPd, Curi R, Waitzberg DL. Human Leukocyte Death After a Preoperative Infusion of Medium/ Long-Chain Triglyceride and Fish Oil Parenteral Emulsions. Journal of Parenteral and Enteral Nutrition. 2012;36:677-684.10.1177/0148607111432759

31. de la Maza MP, Gotteland Mn, Ramírez C, Araya M, Yudin $T$, Bunout $D$, et al. Acute nutritional and intestinal changes after pelvic radiation. Journal of the American College of Nutrition. 2001;20:637-642,

32. Carvalho PSd, Moreira CLdCB, Barelli MdC, Oliveira FHd, Guzzo MF, Miguel GPS, et al. Cirurgia bariátrica cura síndrome metabólica? Arquivos Brasileiros de Endocrinologia \& Metabologia. 2007;51:79-85.10.1590/ s0004-27302007000100013

33. Elamin NE. Some Physiological Changes Following Intrrmaxillary Fixation (Imf). Khartoum: University of Khartoum; 2006.

34. Novais IP, Puga GM, Sponton CHG, Mallagrino PA, Esposti RD, Zaros PR, et al. Associação entre o polimorfismo do gene do óxido nitrico sintase na posição -786T>C com os níveis plasmáticos de triglicerídeos em mulheres. Rev Dig Buenos Aires 2010;15:5, http:// www.efdeportes.com/efd146/polimorfismo-do-gene-da-oxido-nitrico-sintase.htm

35. Al-Shebli $\mathrm{H}, \mathrm{Al}$-Shayyab $\mathrm{S}$, Younes MNB, Badwan S, Obeidat M, Alshawabkeh A, et al. The clinical impacts of early using glutamine/arginine enriched high 
protein density formula at trophic dose in intolerant enteral nutrition cachectic hypoalbuminemic hospitalized patients. Rom J Intern Med. 2020;10.2478/ rjim-2020-0014.10.2478/rjim-2020-0014

36. Maykish A, Sikalidis AK. Utilization of HydroxylMethyl Butyrate, Leucine, Glutamine and Arginine Supplementation in Nutritional Management of
Sarcopenia-Implications and Clinical Considerations for Type 2 Diabetes Mellitus Risk Modulation. J Pers Med. 2020;10.10.3390/jpm10010019

37. Coëffier M, Déchelotte P. Combined infusion of glutamine and arginine: does it make sense? Curr Opin Clin Nutr Metab Care. 2010;13:70-74.10.1097/ MCO.0b013e328333c27f 